\title{
TIMP3 wt Allele
}

National Cancer Institute

\section{Source}

National Cancer Institute. TIMP3 wt Allele. NCI Thesaurus. Code C52121.

Human TIMP3 wild-type allele is located within 22q12.1-q13.2 and is approximately $62 \mathrm{~kb}$ in length. This allele, which encodes metalloproteinase inhibitor 3 protein, plays a role in extracellular matrix stabilization. Mutations in this gene are associated with Sorsby fundus dystrophy. 